\title{
Leiomyoma of the extrapleural chest wall: an atypical location
}

\author{
Sedat Ziyade ${ }^{1}$, Murat Ugurlucan², Omer Soysal'1, Osman Cemil Akdemir ${ }^{1}$
}

${ }^{1}$ Bezmi Alem Foundation University, Department of Thoracic Surgery, Istanbul, Turkey 2Düzce Ataturk State Hospital, Cardiovascular Surgery Clinic, Düzce, Turkey

Submitted: 17 May 2009

Accepted: 25 July 2009

Arch Med Sci 2011; 7, 2: 356-360

DOI: 10.5114/aoms.2011.22093

Copyright $\odot 2011$ Termedia \& Banach

\begin{abstract}
Tumours of the thoracic wall constitute a wide histological spectrum. However, the literature includes very few reports of a leiomyoma occurring at the extrapleural chest wall. In this report we present our experience together with a review of the literature. Our patient was a 33-year-old woman who was diagnosed with leiomyoma of the chest wall and treated accordingly and successfully. To the best of our knowledge, this is the seventh report in the literature defining the clinical entity.
\end{abstract}

Key words: thorax, chest wall, pleura, leiomyoma, surgery.

\section{Introduction}

Leiomyomas are benign soft tissue tumours which take origin from the smooth muscles. They are classified in the mesenchymal tumour family [1]. The first definition of the tumour was made by Virchow [2] in 1854 and Kloepfer et al. [3] described the hereditary form which presented with multiple leiomyomas [4, 5]. Although the multiple form has been defined in general, these neoplasms are regarded as benign curable tumours.

Leiomyomas may occur in any body parts where smooth muscles are present. According to the location of the tumour, there are three distinct types of leiomyomas: piloleiomyomas, angioleiomyomas, and genital leiomyomas [4-9]. On the other hand, when the name is announced, the recall indicates that they are located in the uterus or gastrointestinal tract, being more frequent in the small intestine and oesophagus [1]. Additionally, there are reports of leiomyomas defining the origin even from the arrector pili muscle of the pilosebaceous unit [9].

The thorax is a very atypical region for the tumour origin. Leiomyoma originating in the thoracic cavity is an extremely rare clinical entity and the literature includes only sporadic reports describing leiomyomas of the extrapleural chest wall [1, 10-16].

The purpose of this manuscript is to present our single case experience on the clinical entity and make a review of the literature about the pathology described up to the present moment.

\section{Case report}

A 33-year-old multiparous female patient without any previous history of systemic and familial disorders was referred to the clinic with chest

\author{
Corresponding author: \\ Dr. Murat Ugurlucan \\ Bozkurt Caddesi, No: 110-112 \\ Benli Apt., Daire: 6 \\ 80250 Kurtulus/Istanbul \\ Turkey \\ Phone: +90 5354316786 \\ Fax: +90 2122352568 \\ E-mail: \\ muratugurlucan@yahoo.com
}


pain and heartburn for 2 years. She had multiple family doctor visits and was treated due to pyrosis. Increase in the symptoms and the pain of the patient led to her referral to our unit. She complained of an increasing pain at the left upper border of the sternum irrespective of exercise. Physical examination was completely normal with normal temperature $\left(36.7^{\circ} \mathrm{C}\right)$, breath sounds (rate: $14 / \mathrm{min}$ ), heart rate ( 68 beats/min) and blood pressure $(110 / 60 \mathrm{mmHg})$. Laboratory findings did not reveal any abnormalities except hyperlipidaemia (total cholesterol: 253 mg/dl; N: 125-200 mg/dl). Chest X-ray showed a lesion at the left upper hemithorax (Figure 1). Pathology was confirmed with computed tomography and it revealed a wellcircumscribed solitary lesion with a wide base located on the parietal pleura of the upper left chest wall which also led to a certain degree of destruction on the second rib (Figure 2). Bronchoscopy was normal and a bronchial lavage was reported to be benign.

An explorative diagnostic and therapeutic strategy was planned and after the consent of the patient was obtained, surgical treatment was performed through left anterior thoracotomy. There was an encapsulated mass lesion measuring $5.3 \times 4.0 \times$ $3.4 \mathrm{~cm}$ originating from the apex of the chest wall. On inspection there was low grade vascularization of the mass. The tumour was excised totally (Figure 3) by abrading from the rib. The second rib was healthy and was left in place. Frozen section study of the specimen indicated a benign lesion. Histopathological examination revealed strong smooth muscle actin positivity, probably caused by a leiomyoma (Figures 4-6). The postoperative course was uneventful and the patient was discharged from the hospital on the fourth postoperative day. She visits our outpatient clinic regularly and is symptom free 14 months postoperatively.

\section{Discussion}

Leiomyomas are soft tissue tumours originating from smooth muscles. They were first described by Virchow in 1854 [2]. They can develop wherever smooth muscles are present; however, they usually occur in the uterus, small intestine or oesophagus [1, 4-9]. Although theoretically the latter is correct, smooth muscle neoplasms originating from the serous membranes are extremely rare and reports of intrathoracic leiomyomas exist only in a few case report studies [10-16] rather than large series in the literature.

When they are located in other than well-known locations, i.e. oesophagus, small intestine or uterus, generally they are symptom free and detected by chance while performing routine check-up measures or diagnostic studies for other pathologies [4-9]. Among the 6 published cases [10-16],
5 were asymptomatic $[10,12,13,15,16]$, one had chest pain [11], and one had chest pain and empyema [14]. In our case the patient complained of pain and heartburn. There appear atypical, unfamiliar lesions on radiographic films which cannot be differentiated from other soft tissue

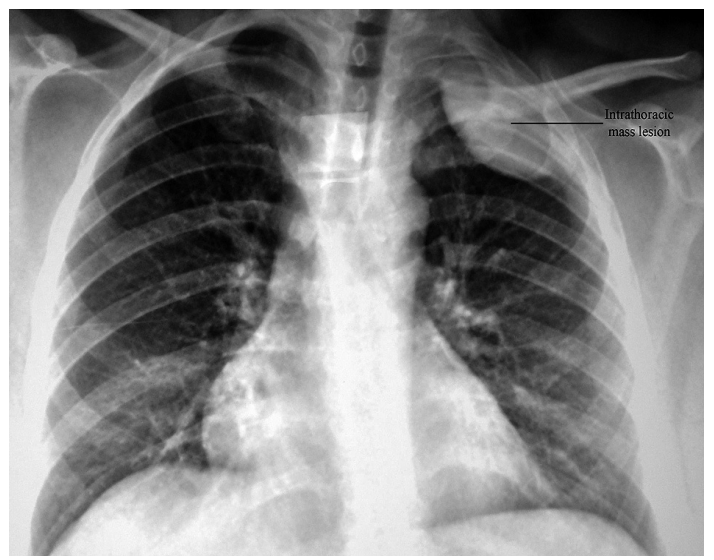

Figure 1. Chest X-ray indicating the lesion at the left upper hemithorax

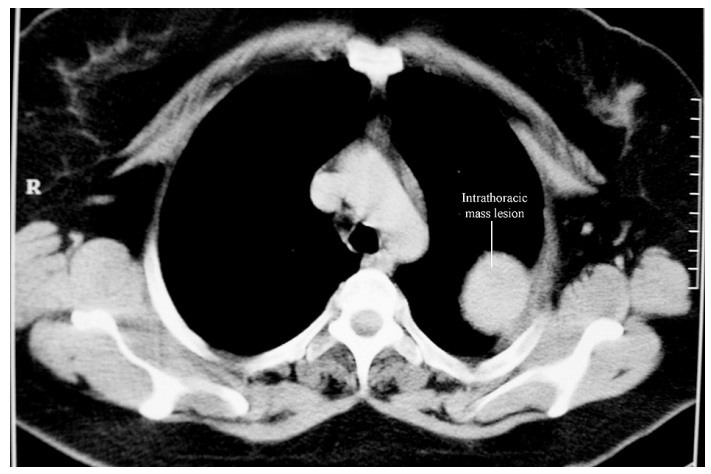

Figure 2. Computed tomography indicating a wellcircumscribed solitary lesion with a wide base located on the parietal pleura of the upper left chest wall and leading to a certain degree of destruction on the second rib

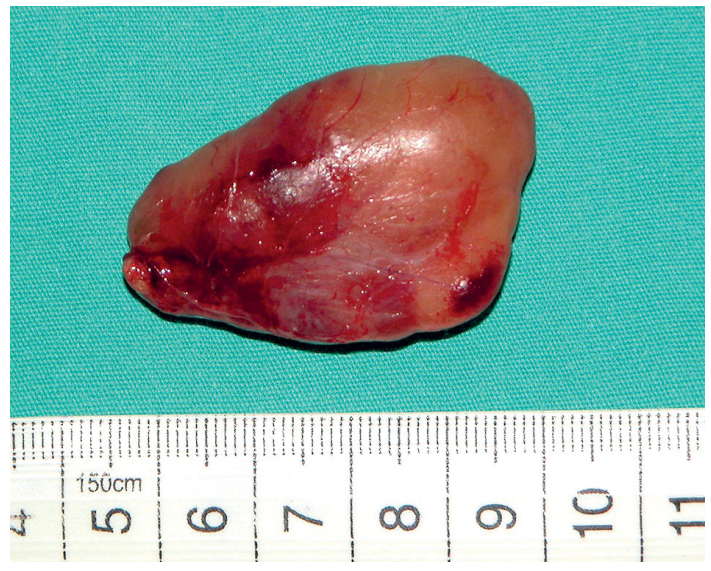

Figure 3. The excised mass lesion measuring $5.3 \times$ $4.0 \times 3.4 \mathrm{~cm}$ 


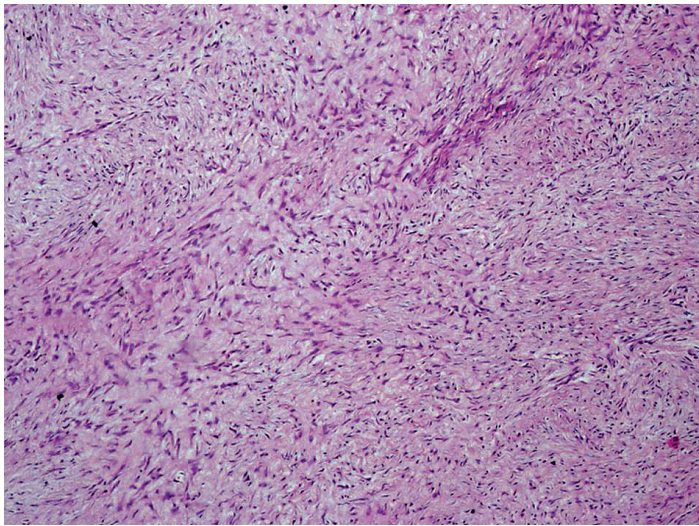

Figure 4. Haematoxylin and eosin staining indicating proliferating spindle cells with cigar-shaped nuclei and multiple vascular channels $(\times 100$, Olympus DP2BSW)

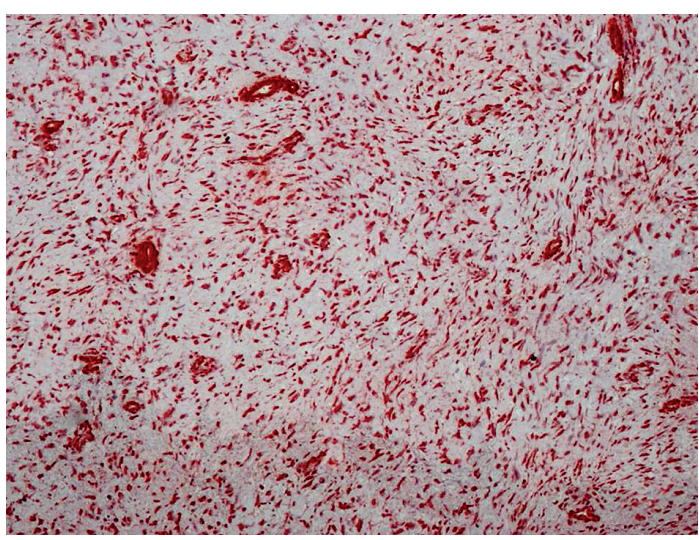

Figure 5. Strong smooth muscle actin positivity detected by anti-SMA immunostaining $(\times 100$, Olympus DP2BSW)

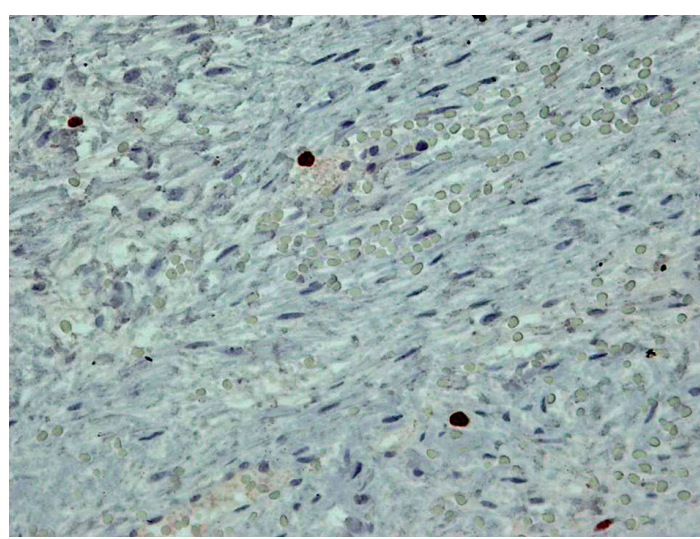

Figure 6. Immunohistochemical staining for Ki-67 indicated that the tumour had a low score, which indicated a benign lesion $(\times 400$, Olympus DP2BSW)

tumours of the chest $[1,10,11]$. Histopathological examination is required for the definitive diagnosis.

Leiomyomas are classified according to the origin of the tumour. Accordingly, there are three distinct types of leiomyomas: piloleiomyomas, indicating the origin of the tumour from the arrector pili muscle of the pilosebaceous unit; angioleiomyomas, originating from smooth muscle - the tunica media layer within the arterial and/or venous wall; and genital leiomyomas, showing a wide range of region of origin such as muscle of the scrotum, the labia majora, and erectile muscle of the nipple [17]. It is believed that tumours in each classification have unique clinical and histopathological characteristics $[2,3]$.

The literature contains 6 published cases of leiomyomas originating from the chest wall [2-8]. Nose et al. [10], Turhan et al. [11], Proca et al. [12], and Tanaka et al. [13] presented their single case experiences, whereas Moran et al. [14, 15] presented two sporadic cases of leiomyomas of the chest wall. Tumours including our case originated from the vascular smooth muscle in four cases $[11,14,15]$ and from the microvascular wall in two cases [10, 13], whereas Proca et al. [12] did not define the origin of the tumour exactly in their manuscript. Usually the tumours were solitary and could be resected completely [10-12]; however, due to the extent of the disease, Moran et al. $[14,15]$ reported that complete resection was not possible. Being completely or partially resected, the longest followup has been provided by Turhan et al. [11] with up to 53 months. Like the other authors [10-16], they indicated cure with complete resection [10-12]. On the other hand, for the two cases of Moran et al. $[14,15]$, volume reduction surgery has also been effective and their 4-6 months follow-up results with partial resection did not indicate malignant transformation, metastasis or enlargement in the tumour size.

Metastasis of uterine leiomyomas years after hysterectomy or myomectomy is a well-known issue and the metastatic lesions of such tumours are named as benign metastasizing leiomyomas [18]. Regions of metastasis may include lungs, lymph nodes, bones, central nervous system and heart. These locations are shown to be associated with the presence of oestrogen and progesterone receptors and hormonal therapy has been shown to be effective for the treatment of benign metastasizing leiomyomas $[11,17]$. Like the other solitary leiomyomas reported in the literature [10-16], our case did not have a history of uterine leiomyoma.

Although literally gender preference of the tumour has not been documented for extra-uterine leiomyomas, when we look at the literature for intrathoracic leiomyomas, up to the present moment, among the presented seven cases including our patient, six of them were females [10, 11, 13-16], which may indicate a female predominance and additionally support the oestrogen 
Table I. Characteristics of intrathoracic leiomyomas reported to date

\begin{tabular}{|c|c|c|c|c|c|c|}
\hline Case & Author & Age/gender & Tumour origin & $\begin{array}{l}\text { Tumour size } \\
\qquad[\mathrm{cm}]\end{array}$ & Procedure & $\begin{array}{l}\text { Follow-up } \\
\text { course }\end{array}$ \\
\hline 1 & Turhan et al. & 50 years/F & Vascular smooth muscle & $4 \times 4$ & $\begin{array}{l}\text { Complete } \\
\text { resection }\end{array}$ & $\begin{array}{c}\text { Alive at } \\
53 \text { months } \\
\text { w/o recurrence }\end{array}$ \\
\hline 2 & Nose et al. & 55 years/F & Microvascular wall & $1.5 \times 1.5$ & $\begin{array}{l}\text { Complete } \\
\text { resection }\end{array}$ & $\begin{array}{c}\text { Alive at } \\
26 \text { months } \\
\text { w/o recurrence }\end{array}$ \\
\hline 3 & Tanaka et al. & 40 years $/ F$ & Microvascular wall & $3.5 \times 3$ & $\begin{array}{l}\text { Complete } \\
\text { resection }\end{array}$ & $\begin{array}{c}\text { Alive at } \\
17 \text { months } \\
\text { w/o recurrence }\end{array}$ \\
\hline 4 & Proca et al. & 32 years/M & No details & $\begin{array}{l}\text { First diagnosis: } \\
\qquad \begin{array}{l}3 \times 5.2 \\
\text { Second diagnosis: } \\
4.3 \times 7 \\
\text { (intrathoracic } \\
\text { portion) } \\
+ \\
4 \times 6 \\
\text { (extrathoracic } \\
\text { portion) }\end{array}\end{array}$ & $\begin{array}{c}\text { Detected } \\
\text { with needle } \\
\text { biopsy and } \\
\text { followed due } \\
\text { to benign } \\
\text { behaviour. } \\
\text { Resected } \\
\text { completely } \\
\text { with part } \\
\text { of the anterior } \\
\text { chest wall } \\
\text { and a segment } \\
\text { of the third } \\
\text { rib } 4 \text { years } \\
\text { later }\end{array}$ & $\begin{array}{c}\text { Alive at } \\
12 \text { months, } \\
\text { w/o recurrence }\end{array}$ \\
\hline 5 & Moran et al. & 23 years/F & $\begin{array}{c}\text { Vascular smooth } \\
\text { muscles }\end{array}$ & $10 \times 9 \times 5.5$ & $\begin{array}{l}\text { Resected } \\
\text { partially }\end{array}$ & $\begin{array}{c}\text { Alive at } \\
6 \text { months } \\
\text { w/o enlargement } \\
\text { or metastasis } \\
\text { of the tumour }\end{array}$ \\
\hline 6 & Moran et al. & 21 years/F & $\begin{array}{c}\text { Vascular smooth } \\
\text { muscles }\end{array}$ & $\begin{array}{l}\text { Unresectably } \\
\text { huge }\end{array}$ & $\begin{array}{l}\text { Resected } \\
\text { partially }\end{array}$ & $\begin{array}{c}\text { Alive at } \\
6 \text { months } \\
\text { w/o enlargement } \\
\text { or metastasis } \\
\text { of the tumour }\end{array}$ \\
\hline 7 & Our case & 33 years/F & $\begin{array}{c}\text { Vascular smooth } \\
\text { muscle }\end{array}$ & $5.3 \times 4 \times 3.4$ & $\begin{array}{c}\text { Resected } \\
\text { completely }\end{array}$ & $\begin{array}{c}\text { Alive at } \\
14 \text { months } \\
\text { w/o recurrence }\end{array}$ \\
\hline
\end{tabular}

F-female, $M$ - male, $\mathrm{cm}$-centimetres, w/o-without

and progesterone receptor theory for atypically located leiomyomas.

Leiomyomas are classified as benign tumours although histopathologically they may include proliferating spindle cells with cigar-shaped nuclei. They usually do not contain mitotic figures or cellular dysplasia [10]. However, as in the cases of Proca et al. [12] and Moran et al. [14, 15], the tumour may exhibit local invasion characteristics which may complicate complete resection. Even after partial resection the course of the disease is still benign.

In conclusion, a leiomyoma originating from the extrapleural chest wall is an extremely rare clinical presentation and to the best of our knowledge, this is the seventh report in the literature presenting a chest wall leiomyoma. According to the review of the literature with this modest extent, when located in atypical regions, these tumours are generally benign, and usually completely resectable. Complete resection generally results in cure, and partial resection for unresectably huge tumours significantly decreases the symptoms without long-term evidence of size enlargement of the remaining lesion.

\section{Acknowledgments}

The authors would like to thank Ms. Toni Spring and Ms. Rosalind Adnitt for the linguistic revision of the manuscript. 


\section{References}

1. Anderson BO, Burt ME. Chest wall neoplasms and their management. Ann Thorac Surg 1994; 58: 1774-81.

2. Virchow R. Ueber Makroglossie und pathologische Neubildung quergestreifter Muskelfasern. Virchows Arch (Pathol Anat) 1854; 7: 126-38.

3. Kloepfer HW, Krafchuk J, Derbes V. Hereditary multiple leiomyoma of the skin. Am J Hum Genet 1958; 10: 48-52.

4. Vellanki LS, Camisa C, Steck WD. Familial leiomyomata. Cutis 1996; 58: 80-2

5. García Muret MP, Pujol RM, Alomar A, et al. Familial leiomyomatosis cutis et uteri (Reed's syndrome). Arch Dermatol Res 1988; 280 Suppl: S29-32.

6. Ramesh P, Annapureddy SR, Khan F, et al. Angioleiomyoma: a clinical, pathological and radiological review. Int J Clin Pract 2004; 58: 587-91.

7. Spencer JM, Amonette RA. Tumors with smooth muscle differentiation. Dermatol Surg 1996; 22: 761-8.

8. Brooks JK, Nikitakis NG, Goodman NJ, et al. Clinicopathologic characterization of oral angioleiomyomas. Oral Surg Oral Med Oral Pathol Oral Radiol Endod 2002; 94: 221-7.

9. Raj S, Calonje E, Kraus M, et al. Cutaneous pilar leiomyoma: clinicopathologic analysis of 53 lesions in 45 patients. Am J Dermatopathol 1997; 19: 2-9.

10. Nose $\mathrm{N}$, Inoue $\mathrm{M}$, Kodate $\mathrm{M}$, et al. Leiomyoma originating from the extrapleural tissue of the chest wall. Jap J Thorac Cardiovasc Surg 2006; 54: 242-5.

11. Turhan K, Cakar A, Cagirici U. Leiomyoma: an unusual pleural tumor: report of a case. Turk Resp J 2008; 9: 53-5.

12. Proca DM, Ross P, Pratt J, et al. Smooth muscle tumor of pleura: a case report and review of the literature. Arch Pathol Lab Med 2000; 124: 1688-92.

13. Tanaka T, Adachi A, Iwata S, et al. A case of leiomyoma of the chest wall. Nippon Kyobu Geka Gakkai Zasshi 1992; 40: $1721-4$

14. Moran CA, Suster S, Koss MN. Smooth muscle tumors presenting as pleural neoplasms. Histopathology 1995; 27: 227-34

15. Moran CA, Suster S, Koss MN. Smooth muscle tumors of pleura. Histopathology 1997; 30: 97-8.

16. Park SY, Lim EJ, Jang JS, et al. Benign metastasizing pulmonary leiomyoma with hemoptysis. Tuberc Respir Dis 2006; 60: 92-6.

17. Toida M, Koizumi H, Shimokawa K. Painful angiomyoma of the oral cavity: report of a case and review of the literature. J Oral Maxillofacial Surg 2000; 58: 450-3.

18. Rivera JA, Chiristopoulos S, Small D, et al. Hormonal manipulation of benign metastasizing leiomyomas: report of two cases and review of the literature. J Clin Endocrinol Metab 2004; 89: 3183-8. 